\title{
Agrophysiological responses of cotton to time and type of stress moderators on different planting date under saline conditions
}

\author{
Zeinab Borzouyi \\ Sabzevar Branch, Islamic Azad University \\ Mohammad Armin ( $\nabla$ moh_armin@yahoo.com) \\ Sabzevar Branch, Islamic Azad University https://orcid.org/0000-0002-2228-7204 \\ Mamid Harvi \\ Sabzevar Branch, Islamic Azad University
}

\section{Research}

Keywords: Cotton, Glycine betaine, Salicylic acid, Salinity, Sodium nitroprusside, Sowing date

Posted Date: April 21st, 2021

DOI: https://doi.org/10.21203/rs.3.rs-425172/v1

License: (c) (i) This work is licensed under a Creative Commons Attribution 4.0 International License. Read Full License 


\section{Abstract}

Background: Today, stress moderators are employed for mitigating the negative effects of environmental stress as the main cause of reduced yields of crops. In this study, the impacts of time and types of stress moderators on agrophysiological responses of cotton under saline conditions on different planting dates were investigated during 2017 and 2018. A split-plot factorial experiment was carried out in a randomized complete block design with 3 replications. Sowing dates (early and late) were considered as the main plots and stress moderator type at 4 levels (control, 2mM Salicylic acid (SA), $100 \mathrm{mM}$ Glycine betaine (GB), and $100 \mu \mathrm{M}$ sodium nitroprusside (SNP)) and application time (flowering and flowering+bolling stages) were regarded as the sub plots.

Results: The delayed planting reduced plant height, reproductive branch number, number of bolls, boll weight, 1000-seed weight, biological yield, seed cotton yield, lint yield, chlorophyll a, chlorophyll b, carotenoids, total chlorophyll, sodium, potassium and proline content. Spraying with the stress moderators alleviated soil salinity effects on yield, yield components and biochemical traits of cotton. SA spraying led to maximum height, 1000-seed weight, biological yield, seed cotton percentage, seed cotton yield, and potassium content. SNP spraying yielded the greatest number of bolls per plant, boll weight, lint yield, and proline content. The highest plant height, chlorophyll a, chlorophyll b, carotenoids and total chlorophyll content resulted from GB spraying. Yield, yield components, and biochemical traits did not respond to the stress moderator types in the delayed sowing date, while the highest chlorophyll a, carotenoids, proline content, the number of bolls per plant and seed cotton yield was resulted from spraying with SNP in early planting. No statistically significant differences were observed between spraying with SNP and SA in most studied traits.

Conclusions: The result suggests that cotton planting at an appropriate date and SNP spraying could be recommended for producing the most suitable yield under saline conditions.

\section{Highlights}

External application of stress modulators increases salinity stress tolerance.

Spraying with sodium nitroprusside has more moderating effect.

Agro-physiological response of cotton to moderators is higher in early sowing.

Maximum seed cotton yield was achieved at early sowing and spraying sodium nitroprusside.

Delayed cultivation reduces cotton yield.

\section{Introduction}

Environmental stress has been always regarded as one of the main causes of lowered yields in agricultural crops. Among the various types of environmental stresses, salinity stress is the cause of more than $50 \%$ 
reduction in crop yields (Liu et al. 2020). Although cotton is considered a semi-salinity-resistant plant, salinity has negative effects on its growth and development (Ahmed et al. 2020). Different strategies, such as managing the type of fertilizer, time of fertilizer application, planting pattern, use of resistant cultivars, and today's use of stress moderators, have been employed to alleviate the effects of salinity stress on crops. For example, improving effects of SNP (Rezapour et al. 2019), SA and putrescine (Bagheri and Mohammadalipour 2011; Yildirim et al. 2008), ascorbic acid, brassinosteroids, and melatonin tocopherols (Xiao et al. 2019), which have been reported for amelioration of tolerance to salinity stress in cotton. GB spraying in cotton has been reported to augment lint yield, number of bolls, number of reproductive branches, and plant height and reduce boll shedding percentage and early germination, but it has no significant effects on the 20-boll weight (Ali et al. 2010). In addition to GB, SA and SNP are also applied to alleviate salinity stress effects. Today, both of these substances are classified as plant hormones. Concerning the external application of SNP in cotton, it has been reported that its foliar application of 0.05 $M$ increases yield and yield components, pigment contents, total soluble sugars, proline content, total free amino acids, phenolic content, and soluble proteins, as well as antioxidant and antioxidant enzyme activities (Shallan et al. 2012). Noreen et al. (2012) also reported an increase in cotton growth and yield with SA consumption.

Among the important agricultural factors, sowing date is significant for maximizing access to resources (Bagherabadi et al. 2019). In many parts of Iran, cotton cultivation is delayed by about 1 month of the proper sowing date in order to harvest winter wheat and barley (Bagherabadi et al. 2019). Sedighi et al. (2012) reported that the delays in cotton planting reduced its lint yield so that its cultivation after harvesting barley lowered its yield by more than $30 \%$ compared to its timely sowing. Low yields caused by late cotton cultivation compared to its planting at the optimal date have been attributed to its reduced reproductive period, decreased temperature leading to heat stress during early growth stages, shortened day length, and lower solar radiation than desired during the reproductive stages (Rahman et al. 2019).

Due to the relatively good tolerance of cotton to salinity stress, cultivation of this plant in saline soils has been considered by many farmers. Therefore, finding a simple solution for increasing its yield in saline conditions can lead to its proper economic production. Although the use of stress moderators is now considered as a practical and low-cost method for alleviating the effects of environmental stresses on crops, little information exists about the effects of foliage time and moderator type on cotton yield and yield components. Hence, the aim of this research was to investigate the responses of cotton to the time and type of stress moderator in different planting date under soil salinity conditions.

\section{Materials And Methods}

This research was conducted in a private farm, which was located $10 \mathrm{~km}$ from Sabzevar at the geographical latitude of $36^{\circ} 13-\mathrm{N}$, longitude of 57 $44-\mathrm{E}$ and altitude of $990 \mathrm{~m}$ above sea level, during 2017 and 2018. The meteorological data for cotton growth period are given in Table 1.

A split-plot factorial experiment was carried out in a randomized complete block design with 3 replications. Sowing dates (early and late) were considered as the main plots and stress moderator type at 4 levels 
(control, $2 \mathrm{mM}$ Salicylic acid (SA), $100 \mathrm{mM}$ Glycine betaine (GB), and $100 \mu \mathrm{M}$ sodium nitroprusside (SNP)) and application time (flowering and flowering+bolling stages) were regarded as the sub plots. In the study area, the early sowing date and delayed cultivation are usually conducted from the $6^{\text {th }}$ of May and June (after harvesting barley or wheat) onward, respectively. The experimental plots had been laid fallow and allocated to wheat cultivation during the previous years of the $1^{\text {st }}$ and $2^{\text {nd }}$ experimental years. Land preparation was done with deep plowing in the fall of the previous year in first year and after wheat harvesting in second year and tillage operation included surface plowing, double disc plowing, and complete leveling in May. Before planting, Soil samples were taken at depths of 0 to $30 \mathrm{~cm}$, and physicochemical properties were detrmined (Table 2).

According to the soil test, $160 \mathrm{~kg}$.ha-1 ${ }^{-1}$ of nitrogen from urea source was applied in the 3 stages: planting time (45 kg.ha-1), first weeding (70 kg.ha-1), and early flowering $\left(45 \mathrm{~kg} \cdot \mathrm{ha}^{-1}\right)$, along with $70 \mathrm{~kg} \cdot \mathrm{ha}^{-1}$ of $\mathrm{P}_{2} \mathrm{O}_{5}$ from triple superphosphate source before planting. Prior to sowing, the seeds were disinfected with Carboxin-Thiram

(Vitavax) at a ratio of \%o2. To combat thrips pest, they were impregnated with Larvin (thiodicarb) at a ratio of $\% \circ 7$. There were 6 planting rows in each plot, with a row spacing of $50 \mathrm{~cm}$ and plant spacing of $20 \mathrm{~cm}$.

The early sowing dates occurred in May 4, 2017 and April 30, 2018 and the delayed cultivations were in June 9, 2017 and June 7, 2018 in the $1^{\text {st }}$ and $2^{\text {nd }}$ years, respectively. In the $2^{\text {nd }}$ year, planting occurred after harvesting wheat with a combine harvester. The remaining straw and stubble were first collected with a blender and the other plant residues were mixed with soil using a rotating plow. Planting was done by using the delinted seeds of Varamin cultivar and a pneumatic sowing machine. To prevent soil crusting and improve the germination condition of cotton seedlings, the $2^{\text {nd }}$ irrigation was performed 10 days later. Irrigation was carried out according to depletion of $40 \%$ of the total available water from the root-zone during the whole experiment. After complete establishment and in the 5-6-leaf-growing stage, the plants were thinned on the rows at a distance of $20 \mathrm{~cm}$ from each other in order to achieve the desired density. Weeding operations were performed manually.

In each of the two experimental years, the third terminally evolved leaves were selected 2 weeks after applying the stress-moderating treatments and their physiological traits were measured based on their wet weights. The amounts of photosynthetic pigments (chlorophyll a, chlorophyll b, total chlorophyll, and carotenoids) were measured according to Arnon (1967) method and the concentrations of the pigments were calculated in milligrams per gram of fresh weight $\left(\mathrm{mg} \mathrm{g}^{-1} \mathrm{FW}\right)$. The method presented by Bates et al. (1973) was employed to measure proline contents of the leaf tissues. The concentrations of sodium and potassium elements were measured with a JENWAY PFP7 flame photometer.

At harvest time, 10 plants were randomly selected and their final heights, numbers of reproductive branches, numbers of bolls per plant, and boll weights were measured. For determining of biological and seed cotton yield after eliminating guard lines remained area was harvested and biological and seed cotton yield were measured. The seed cotton and lint were then segregated from seed cotton yield and weighed separately and the lint and seed cotton yields were calculated. To determine 1000-seed weight of 
cotton, 100 cotton seeds were randomly separated and weighed using a digital scale with an accuracy of $0.01 \mathrm{~g}$. At the end, the collected data were analyzed using SAS statistical software. Also, to compare the means, the LSD test was utilized at $5 \%$ level of confidence and Excel software was applied to draw the figures.

\section{Results}

\section{Yield and yield components}

Delay in planting caused $36.2,21.6,49.3,35.5,50.7,62.1,20.9,69.7$, and $36.05 \%$ reductions in the final height, number of reproductive branches, number of bolls per plant, average weight of 10 bolls, biological yield, seed cotton yield, seed cotton percentage and lint yield respectively (Table 3).

There was a statistically significant difference in plant height, the number of bolls, boll weight, seed cotton yield, and lint yield between foliar application at the flowering+bolling and flowering stages. Foliar application at the flowering+bolling stage increased plant height, the number of bolls, boll weight, lint yield, and seed cotton yield by $8.8,34,7.09,17.81$, and $15.9 \%$ compared to foliar application at the flowering stage, respectively, while the other studied traits did not display any statistically responses to the foliage time (Table 3).

Among the moderators, spraying with SNP led to the greatest effects on increasing height, boll weight, and lint yield, while spraying with SA after SNP produced a higher final height. Although the use of GB enhanced boll weight by $32.7 \%$ compared to the control, the boll weights were 4.92 and $9.05 \%$ lower than SA and SNP applications, respectively (Table 3). Additionally, no statistically significant difference was observed between foliar applications with SNP and SA in terms of lint yield. SA foliar application produced the highest 1000-seed weight, biological yield, and seed cotton percentage. Spraying with GB and SNP did not result in a statistically significant difference in terms of 1000-seed weight and biological yield, while a statistically significant difference was witnessed between spraying with SA and GB in terms of seed cotton percentage. Compared to the control, foliar application with GB increased the number of reproductive branches, but their highest number was obtained by foliar application with SNP, which did not have a statistically significant difference from that achieved by SA foliar application (Table 3).

Plant height did not respond to foliage time in the delayed cultivation, while foliar application at the flowering+bolling stage led to a higher plant height compared to foliar application at the flowering stage in the early sowing date (Table 4). Both in the early and late sowing date, foliar application at the flowering+bolling stage produced more bolls per plant compared to foliar application at the flowering stage. The highest (16.9) and lowest (6.86) numbers of bolls per plant were seen with foliar applications at the flowering+bolling and flowering stages in the early and delayed cultivation, respectively (Table 4). In the delayed cultivation, boll weight did not respond to the application time of the stress moderators, while foliar application at the flowering+bolling stage led to $10.6 \%$ more boll weight compared to foliar application at the flowering stage in the early sowing date (Table 4). Lint yield revealed the greatest response to the consumption times of the moderators in both the early and late planting date. In both 
planting date, foliar applications at the flowering+bolling stages led to higher lint yields compared to foliar applications in the flowering stage $(19.89 \%$ greater lint yield in the early sowing date compared to the delayed cultivation). The 1000 -seed weight responses to the foliage time and sowing date were similar to those of boll weight (Table 4).

As with the foliage time, the type of moderator used affected the final height only in the early sowing date, but the height did not indicate a statistically significant response to the use of moderators in the delayed cultivation although the use of moderators elevated height compared to the control. In the early sowing date, foliar application with GB did not have a significant effect on height and was statistically identical to the control treatment, while foliar application with SNP and SA enhanced height by 22.15 and $21.32 \%$ compared to the control, respectively. Compared to the control, foliar spraying with the moderators augmented the numbers of bolls per plant by 70.2 and $48.3 \%$ in the early sowing and delayed cultivation, respectively. In the early and late sowing date, spraying with SNP and SA produced the highest numbers of bolls per plant, respectively. There was no significant difference between SNP and SA spraying in the delayed cultivation as no significant difference was seen between SNP and GB spraying in the early sowing date (Table 5). In both the early and late sowing date, foliar application with SA yielded more biological yield compared to the other stress moderators. In the delayed cultivation, the use of SNP reduced biological yield compared to GB, which was similar to that of the control, while foliar application with SNP produced a similar biological yield to SA in the early sowing date. In the delayed cultivation, lint yield depicted less response to the type of consumed moderator and all the moderators had a statistically similar effect on the lint yield. In the early sowing date, although GB spraying produced more lint yield compared to the control treatment, the highest lint yield was observed with SNP spraying. The use of stress moderators increased seed cotton yield in both early and late sowing date. The response of seed cotton yield to the type of moderator utilized in the early sowing date was higher, while SNP, SA, and GB had statistically similar impacts on the seed cotton yield in the delayed cultivation; however, foliar application with SA produced higher seed cotton yield in the early cultivation, which was not statistically significantly different from that induced by SNP consumption (Table 5).

Foliar spraying of all the moderators studied in this experiment yielded a higher lint yield in the flowering+bolling stage compared to foliar application in the flowering stage. SA foliar application in the flowering+bolling stage produced the highest lint yield, while its non-foliar application produced the lowest yield. There was no statistically significant difference between foliar applications with SA and SNP in the flowering+bolling stage (Fig. 1).

Foliar applications of all the stress moderators produced more seed cotton yield in the flowering+bolling compared to the flowering stage. The highest seed cotton yield was observed with SA foliar application in the flowering+bolling stage, which was not statistically significantly different from SNP application at this stage of the plant growth. Yet, a higher percentage of seed cotton yield (28.75\%) was seen with GB foliar application compared to the other moderators in the flowering+bolling stage, while the enhancements were 18 and $11.18 \%$ for SA and SNP, respectively (Fig. 2). 
Delay in planting lowered the contents of chlorophyll a, chlorophyll b, carotenoids, and total chlorophyll by $52.1,33.9,23.2$, and $43.8 \%$, respectively (Table 6). Foliar application in the flowering+bolling stage increased chlorophyll a, chlorophyll b, and total chlorophyll contents in comparison with foliar application in the flowering stage. Among the consumed moderators, spraying with SNP had more beneficial effects on enhancing chlorophyll pigments compared to the other stress moderators. Although GB spraying augmented the contents of chlorophyll pigments in comparison with the control group, it had less elevating effects compared to the other moderators. Compared with the control, SNP spraying increased the contents of chlorophyll a, chlorophyll b, total chlorophyll, and carotenoids by $137,158,89$, and $128 \%$, respectively (Table 6).

The content of proline accumulated in the leaves was higher in the early sowing date compared to the delayed cultivation. Foliar spraying at the flowering+bolling stage also enhanced proline amount compared to foliar application at the flowering stage. Comparison of the means of the treatments revealed that the highest proline content was obtained with SNP spraying, which did not have a statistically significant difference from that of SA. The lowest proline amount was observed in the non-spraying treatment. GB spraying also enhanced proline content compared to the control (Table 6).

Both the amounts of sodium and potassium content were higher in the early sowing date compared to the delayed cultivation. Foliage time had only a significant effect on potassium content and foliar application at the flowering+bolling stage displayed more effects compared to foliar application at the flowering stage. Under the conditions of this study, foliar application with SA played a greater role in reducing sodium content compared to the other moderators, while potassium content was not affected by the type of moderator used (Table 6).

At all levels of the consumed moderators, chlorophyll a content was lower in the delayed cultivation compared to the early sowing date (Table 7). Nonetheless, in both cultivations, spraying with SNP had more increasing effects on chlorophyll a contents compared to the other moderators. In the early sowing date, foliar application with SA had no statistically significant difference from foliar application with SNP and spraying with SA and GB were not statistically significantly different in the delayed cultivation.

The highest amounts of carotenoids were produced by spraying with SA and SNP in the delayed cultivation and early sowing date, respectively. The contents of carotenoids showed a greater response to foliar applications with the consumed moderators in the delayed cultivation compared to the early sowing date. Compared to the control treatment, spraying with SNP resulted in 108 and 168\% enhancements of the contents of carotenoids in the traditional sowing date and delayed cultivation, respectively (Table 7).

In the early sowing date, proline amount displayed less response to spraying with the different moderator types so that no statistically significant difference was observed between the studied moderators in terms of proline content. However, in the delayed cultivation, spraying with SA produced the highest amount of proline, which significantly differed from spraying with SNP, but was not statistically significantly different from spraying with GB. Although there was no statistically significant difference between the delayed 
cultivation and traditional sowing date in the control treatment, proline amount was higher in the traditional sowing date compared to the delayed cultivation.

In both early and late sowing date, foliar application with SA decreased sodium accumulation in the leaves. In the early sowing date, no statistically significant difference was observed between the stress moderators in terms of reduced accumulation of sodium content, but spraying with GB compared with the other studied moderators led to fewer reductive effects on sodium uptake in the delayed cultivation although it lowered sodium accumulation compared to the control.

In the early sowing date, statistically significant differences were observed between all the consumed moderators in terms of potassium uptake, but no statistically significant difference was seen between spraying with SNP and GB. The highest rates of potassium uptake were documented with spraying with SNP and SA in the traditional sowing date and delayed cultivation, respectively.

\section{Discussion}

The results of this research demonstrated that sowing date has a significant effect on yield components, yield, and physiological traits. These findings are consistent with the previous reports on the effects of sowing date on cotton. It was reported that the cotton cultivated on the $20^{\text {th }}$ of August had a lower height compared to the plants cultivated on the $7^{\text {th }}$ of July (Wrather et al. 2008). Similar to our results, a $25.84 \%$ decrease in the number of reproductive branches associated with delayed sowing was reported by Bagherabadi et al. (2019). The number of bolls per plant was also indicative of the negative response to delayed sowing. According to these results, Panjeh Koub et al. (2008) reported a 22 and $48 \%$ decrease in the number of bolls per unit area accompanied by the delays in the mid-time (June 10) and late (July 1) cotton cultivations compared to the usual sowing date (May 20). Pettigrew (2002) also reported that delays in cotton planting reduced the number of bolls per plant. Despite the higher number of bolls per

plant, a decreased boll weight was expected, but the increase in boll weight in our traditional sowing date might be due to the fact that the boll growth time had been associated with suitable environmental conditions. In contrast, boll formation and development had faced a high temperature and early autumn coldness in the delayed cultivation and as a result, the bolls had not grown and developed well. Similar to these results, Bagherabadi et al. (2019) reported that delays in cotton planting alleviated boll weight by $34.02 \%$. The lower 1000 -seed weight caused by delayed planting is due to the reduced food storage induced by less vegetative growth and lowered current photosynthesis affected by lower leaf area when compared to the traditional sowing date (Bagheri and Mohammadalipour 2011). In cotton, the highest and lowest 1000-seed weights were reported in the traditional sowing date and delayed cultivation, respectively (Krzyzanowski and Delouche 2011). The delays in planting were associated with reduced biological yield. The decrease in biological yield was due to the reductions of height, number of lateral branches, number of bolls per plant, boll weight, and lint weight per boll. Nemati (2000) reported that delays in the sowing date after the $13^{\text {th }}$ of April would alleviate yields. In the same way as the other traits, lint yield showed a similar response to planting delays in our study. Various results have been reported on the effects of sowing date 
on seed cotton percentage. For example, Bednarz et al. (2005) believed that seed cotton growth and development would not fully occur in delayed sowing conditions, which could lower lint percentage.

Our studied traits indicated little response to the spray time. It seemed that the reason for non-responding to the foliage time in the delayed cultivation was the short time period between the two consumables. In this condition, cotton went through its vegetative stages earlier due to high temperatures and thus the transit from the flowering to the bolling stage occurred rapidly. The use of moderators might have even had negative effects on the plant growth and development due to the enhanced doses, leading to the lack of response to the foliage time. In dry stress conditions, spraying SA at a concentration of $100 \mathrm{mg} \cdot \mathrm{L}^{-1}$ in the flowering stage compared to foliar applications of GB and proline was reported to produce more beneficial effects in increasing yield and yield components in cotton, while the stress-moderating effects of GB were greater than those of proline (Noreen et al. 2012). Foliar spraying with GB during the flowering stage failed to produce good yield and did not thus have a statistically significant difference from the control treatment. Heitholt et al. (2001) linked cotton response to SA foliar application at different growth times to its increased resistance to diseases, insects, and microbes.

In our study, spraying with the stress moderators increased yield and yield components. It has been reported that SNP increases cotton plant growth and its stem and root lengths in salinity stress. The enhanced plant growth is due to the augmented cell osmotic pressure and improved cytoplasmic viscosity though high SNP concentrations would inhibit seedling growth (Dong et al. 2006). SA foliar application also increases the amounts of indoleacetic acid and cytokinin in salinity conditions and thus enhances height. Meek et al. (2003) reported that foliar application of GB led to a significant increase in the number of reproductive branches (having at least one boll per branch) compared to its non-consumption treatment. Similar to the above results, Zhang et al. (2011) reported that the numbers of reproductive branches and leaf areas in cultivars that lack the ability to accumulate and synthesize GB and in transgenic lines capable of synthesizing it were statistically identical. Foliar application with SA enhances the number of bolls per plant by reducing transpiration rate, especially at high temperatures (Heitholt et al. 2001). As with the other yield components, 1000-seed weight was elevated by spraying with the stress moderators. The use of stress modulators increases the period length and seed-filling rate, thus enhancing 1000-seed weight (Bagheri and Mohammadalipour 2011) and preventing reductions of the number of seeds and their weights by augmenting their amounts of photosynthetic materials (Eraslan et al. 2007). With the use of stress moderators, lint yield, seed cotton yield, and seed yield increased. The role of SA in improving biochemical properties, such as contents of soluble and free proteins, photosynthetic pigments, and amounts of plant hormones, and enhancing lint yield under salinity stress conditions has been shown in many plants (Pakar et al. 2016). Wang et al. (2017) reported that SA causes the formation of maximum yield components by regulating plant growth processes, hence augmenting lint yield. In addition, the use of glycine betaine exogen showed to result in 18 to $22 \%$ increases in cotton production (Naidu et al. 1998). In this study, the less response of cotton to the external use of GB appeared to be related to its ability to synthesize or accumulate GB by itself (Zhang et al. 2011). Given that seed cotton percentage was not influenced by foliage time, the enhanced seed cotton yield by foliar application in the flowering+bolling compared to the flowering stage was due to the higher lint yield in this treatment. Despite the high lint yield 
in our SNP treatment, the reduced seed cotton yield could be caused by the greater reduction of seed cotton percentage compared to that triggered by SA foliar application.

Chlorophyll pigments responded to the sowing date and moderator type in a way that with delays in planting, the amounts of chlorophyll pigments decreased, whereas the use of moderators increased them. Studies have shown that photosynthetic pigments are an important determinant of photosynthetic efficiency and plant growth (Pinheiro et al. 2019). Destructions of chloroplasts and photosynthetic structures, chlorophyll photooxidation, reaction with unique oxygen, destruction of chlorophyll synthesis precursors, inhibition of biosynthesis of new chlorophylls, activation of chlorophyll-degrading enzymes like chlorophyllase, and hormonal disorders are among the reasons for the decrease in chlorophyll levels under salinity stress conditions (Neocleous and Vasilakakis 2007). Ma et al. (2017) observed that salinity stress significantly reduced the contents of chlorophylls $a$ and $b$, while treatment with SA reduced the reduction trends of their amounts. The increased role of SA in chlorophyll amounts was ascribed to the stimulation of enzymes associated with chlorophyll biosynthesis or inhibition of photosynthetic system disturbance, thereby alleviating chlorophyll degradation. Moreover, spraying with SA in saline conditions enhanced the contents of chlorophylls a and b, total chlorophyll, and carotenoids in cotton, which is in line with the results of this research. The reinforcing effects of SA on the photosynthetic capacity could be attributed to its stimulating effects on Rubisco's activity and pigment content (Tan et al. 2013). The improving impacts of foliar application with GB on the enhancement of chlorophyll pigment contents in salinity stress conditions have been reported as well. In corn under salinity stress, the external GB application has had an increasing effect on chlorophyll pigments, which is one of the efficient factors in augmenting photosynthetic capacity in salinity conditions (Nawaz and Ashraf 2010).

Under salinity circumstances, proline accumulation takes place as a defense mechanism in plants. Proline is considered a non-toxic protective material to regulate osmosis in salinity and other environmental stresses (Mittler 2002). On the other hand, the accumulated proline in plants increases antioxidant capacity and neutralizes free hydroxyl radicals (Kasote et al. 2015). The external use of stress moderators enhanced proline content in cotton. According to the findings of this research, foliar application of SA in cotton under salinity conditions augmented proline amount, which enabled more resistance to stress via osmotic regulation. In addition, proline acts as an energy source that can help improve tolerance to salinity (EIBeltagi et al. 2017).

There is a difference of absorption between the two ions of sodium and potassium in saline conditions. In high salinity conditions, sodium disrupts potassium uptake by blocking its channels and increasing its leakage. Additionally, sodium can induce non-polarization of the cells by entering the apoplastic space and cause problems in selecting absorption of ions (Keisham et al. 2018). The effects of various factors, such as salinity level or use of plant hormones, on changing the absorption amounts of sodium and potassium ions under salinity stress have been reported by various researchers (Babaei et al. 2020; Ghadakchiasl et al. 2017; Jayakannan et al. 2013; Mohsenzadeh and Zohrabi 2018; Sharif et al. 2019; Zheng et al. 2009). The modulating effects of hormones or semi-hormones in altering the uptakes of sodium and potassium ions are due to changes in plasma membrane permeability (Nadeem et al. 2016). Noreen et al. (2020) reported that the use of stress modulators triggered more potassium uptake by changing plasma membrane 
penetrability. It has been reported that SA plays a greater role in reducing sodium accumulation in root and leaf tissues when salinity increases. Under the salinity level of $5 \mathrm{dS} \cdot \mathrm{m}^{-1}$, no statistically significant difference was observed between the use of gibberellin, cytokinin, and salicylic acid for lowering sodium accumulation; spraying with gibberellin and cytokinin hormones failed to inhibit its accumulation after enhancing salinity to $15 \mathrm{dS} \cdot \mathrm{m}^{-1}$ either. Nevertheless, spraying with SA compared to the control group reduced sodium absorption by $25 \%$. The lower response of sodium amount absorbed in the leaves to the foliar applications of the different consumed moderators seemed to be due to the presence of a salt concentration mechanism in agricultural crops. In fact, the absorbed salt accumulates mostly in the lower and older leaves of the plants in salinity conditions. Nazar et al. (2011) also reported that treatment with SA reduced accumulation of sodium ions in the leaves and increased resistance to salinity. Similar to the above results, the decrease in sodium content and increase in potassium amount with the external use of SA in salinity stress conditions were reported by El-Tayeb (2005).

\section{Conclusion}

Overall, the results of this experiment demonstrated that the delay in cotton cultivation reduced its yield components and ultimately economic performance by mitigating the amounts of chlorophyll pigments and thereby lowering the production of photosynthetic materials. Although in most of the studied traits, no statistically significant differences were observed between spraying during the flowering and flowering+bolling stages, spraying during the flowering+bolling stage was found to be more appropriate than spraying during the flowering stage. Among the moderators applied in this experiment, the external use of SNP had more improving effects on the investigated traits though the external application of SA did not statistically differ from that of SNP in most of the traits either. The external use of GB ameliorated the studied traits compared to non-applications of the stress moderators, but the resulted improvements were lower than those induced by SNP. Spraying with SNP increased cotton resistance to the experimental salinity conditions and thus enhanced yield by alleviating the amount of sodium uptake and augmenting the amounts of chlorophyll pigments and proline and potassium contents. Finally, although the external applications of the stress moderators were not able to compensate for the negative effects of delayed cultivation, SNP consumption during the flowering+bolling stage could be recommended for both early and late sowing date for proper yield achievement.

\section{Abbreviations}

GB: Glycine betaine, SA: Salicylic acid and SNP: sodium nitroprusside, LSD: Least significant difference.

\section{Declarations}

\section{Ethics approval and consent to participate}

Not applicable.

\section{Consent for publication}


All Authors have reviewed the manuscript and given consent for publication.

\section{Availability of data and materials}

Review of data is available upon request.

\section{Competing interests}

All the authors confirm that this manuscript has not been copyrighted or published previously and isnot under consideration for publication elsewhere. The manuscript is approved by all authors, and has no any actual or potential conflict of interest with other people or organizations.

\section{Funding}

Not applicable

\section{Authors' contributions}

Zeinab Borzouyi carried out the study, Mohammad Armin designed the study, analyze the data and wrote the main manuscript text. Hamid marvi helped to fulfill the experiment,. All authors reviewed and approved the final manuscript.

\section{Acknowledgements}

The authors are grateful for the Sabzevar Natural Resources Research Center staff for their time and support in the experiment

\section{Authors' information}

Department of Agronomy and Plant Breeding, Sabzevar Branch, Islamic Azad University, Sabzevar, Iran

\section{References}

Ahmed N, Chaudhry UK, Ali MA, et al. Salinity Tolerance in Cotton. Cotton Production and Uses: Springer; 2020. p. 367-91.

Ali S, Mohammad HF, Mohammad B. Evaluation of Glycine Betaine effects on some agronomic traits of cotton. Jouran of Agronomy Sciences. 2010;1(1):67-76

Babaei S, Niknam V, Behmanesh M. Comparative effects of Nitric Oxide and salicylic acid on salinity tolerance in saffron (Crocus sativus). Plant Biosystems-An International Journal Dealing with all Aspects of Plant Biology. 2020:1-10.https://doi.org/10.1080/11263504.2020.1727975

Bagherabadi H, Armin M, Filekesh E. The effect of sowing date on yield and yield components of cotton planted in ultra narrow rows and conventional rows. Iranian Journal of Cotton Researches. 2019;7(1):114.10.22092/ijcr.2019.108993.1073. 
Bagheri AR, Mohammadalipour Z. The effect of salicylic acid on growth, yield components in (Glycin max L.) under salinity stress. Journal of Plant Ecophysiology. 2011;3(8):29-41

Bates LS, Waldren RP, Teare I. Rapid determination of free proline for water-stress studies. Plant and soil. 1973;39(1):205-7

Bednarz CW, Shurley WD, Anthony WS, et al. Yield, quality, and profitability of cotton produced at varying plant densities. Agronomy Journal. 2005;97(1):235-40

Dong $\mathrm{H}$, Li W, Tang W, et al. Yield, quality and leaf senescence of cotton grown at varying planting dates and plant densities in the Yellow River Valley of China. Field Crops Research. 2006;98(2):106-15

El-Beltagi HS, Ahmed SH, Namich AAM, et al. Effect of salicylic acid and potassium citrate on cotton plant under salt stress. Fresen Environ Bull. 2017;26:1091-100

El-Tayeb M. Response of barley grains to the interactive e.ect of salinity and salicylic acid. Plant Growth Regul. 2005;45(3):215-24.https://doi.org/10.1007/s10725-005-4928-1

Eraslan F, Inal A, Gunes A, et al. Impact of exogenous salicylic acid on the growth, antioxidant activity and physiology of carrot plants subjected to combined salinity and boron toxicity. Scientia horticulturae. 2007;113(2):120-8

Ghadakchiasl A, Mozafari A-a, Ghaderi N. Mitigation by sodium nitroprusside of the effects of salinity on the morpho-physiological and biochemical characteristics of Rubus idaeus under in vitro conditions. Physiol Mol Biol Pla. 2017;23(1):73-83.https://doi.org/10.1007/s12298-016-0396-5

Heitholt J, Schmidt J, Mulrooney JE. Effect of foliar-applied salicylic acid on cotton flowering, boll retention, and yield. Materials and Methods 46 (2): 105-109. 2001

Jayakannan M, Bose J, Babourina O, et al. Salicylic acid improves salinity tolerance in Arabidopsis by restoring membrane potential and preventing salt-induced $\mathrm{K}^{+}$loss via a GORK channel. J Exp Bot. 2013;64(8):2255-68.https://doi.org/10.1093/jxb/ert085

Kasote DM, Katyare SS, Hegde MV, et al. Significance of antioxidant potential of plants and its relevance to therapeutic applications. International journal of biological sciences. 2015;11(8):982

Keisham M, Mukherjee S, Bhatla SC. Mechanisms of Sodium Transport in Plants-Progresses and Challenges. Int J Mol Sci. 2018;19(3):647.https://doi.org/10.3390/ijms19030647

Krzyzanowski FC, Delouche JC. Germination of cotton seed in relation to temperature. Revista Brasileira de Sementes. 2011;33(3):543-8

Liu M, Pan T, Allakhverdiev SI, et al. Crop Halophytism: An Environmentally Sustainable Solution for Global Food Security. Trends in Plant Science. 2020.https://doi.org/10.1016/j.tplants.2020.04.008. 
Ma X, Zheng J, Zhang X, et al. Salicylic acid alleviates the adverse effects of salt stress on Dianthus superbus (Caryophyllaceae) by activating photosynthesis, protecting morphological structure, and enhancing the antioxidant system. Frontiers in plant science. 2017;8:600

Meek C, Oosterhuis D, Gorham J. Does foliar-applied glycine betaine affect endogenous betaine levels and yield in cotton? Crop management. 2003;2(1):0-

Mittler R. Oxidative stress, antioxidants and stress tolerance. Trends in plant science. 2002;7(9):405-10

Mohsenzadeh S, Zohrabi M. Auxin and sodium nitroprusside effects on wheat antioxidants in salinity. Russ J Plant Physl. 2018;65(5):651-7.https://doi.org/10.1134/s1021443718050138

Nadeem SM, Ahmad M, Zahir ZA, et al. Role of phytohormones in stress tolerance of plants. Plant, soil and microbes: Springer; 2016. p. 385-421.

Naidu B, Cameron D, Konduri S, editors. Improving drought tolerance of cotton by glycinebetaine application and selection. Proceedings of the 9th Australian agronomy conference, Wagga Wagga; 1998.

Nawaz K, Ashraf M. Exogenous application of glycinebetaine modulates activities of antioxidants in maize plants subjected to salt stress. J Agron Crop Sci. 2010;196(1):28-37.https://doi.org/10.1111/j.1439037x.2009.00385.x

Nazar R, Iqbal N, Syeed S, et al. Salicylic acid alleviates decreases in photosynthesis under salt stress by enhancing nitrogen and sulfur assimilation and antioxidant metabolism differentially in two mungbean cultivars. J Plant Physiol. 2011;168(8):807-15.https://doi.org/10.1016/j.jplph.2010.11.001

Nemati N. New topics in Cotton farming. Iranian Journal of Agricultural Sciences. 2000;3(2):2-10

Neocleous D, Vasilakakis M. Effects of $\mathrm{NaCl}$ stress on red raspberry (Rubus idaeus L.'Autumn Bliss'). Scientia Horticulturae. 2007;112(3):282-9

Noreen S, Ashraf M, Akram NA. Does exogenous application of salicylic acid improve growth and some key physiological attributes in sunfl ower plants subjected to salt stress? Journal of Applied Botany and Food Quality. 2012;84(2):169-77

Noreen S, Mahmood S, Faiz S, et al. Plant Growth Regulators for Cotton Production in Changing Environment. In: Ahmad S, Hasanuzzaman M, editors. Cotton Production and Uses: Agronomy, Crop Protection, and Postharvest Technologies. Singapore: Springer Singapore; 2020. p. 119-44.

Pakar N, Pirasteh-Anosheh H, Emam Y, et al. Barley growth, yield, antioxidant enzymes, and ion accumulation affected by PGRs under salinity stress conditions. Journal of Plant Nutrition. 2016;39(10):1372-9.10.1080/01904167.2016.1143498.

Panjeh Koub A, Galeshi SA, Zeynali E, et al. Effect of planting date and plant density on morphological characteristics of cotton (Gossypium hirsutum cv. Siokra). Journal of Agricultural Sciences and Natural 
Resources. 2008;14(5):25-38

Pettigrew WT. Improved yield potential with an early planting cotton production system. Agronomy Journal. 2002;94(5):997-1003

Pinheiro FWA, de Lima GS, Gheyi HR, et al. NK combinations do not alleviate the effects of salt stress on gas exchange, photosynthetic pigments and growth of cotton ('Gossypium hirsutum'L.). Australian Journal of Crop Science. 2019;13(8):1353-61

Rahman MH, Ahmad A, Wajid A, et al. Application of CSM-CROPGRO-Cotton model for cultivars and optimum planting dates: Evaluation in changing semi-arid climate. Field Crops Research. 2019;238:139-52

Rezapour R, Ganjali A, Abrishamchi P. Study of Sodium Nitroprusside (SNP) and Salt Stress Interaction on Some Traits of Canola Plant (Brassica napus L. Cv. Modena). Journal of Plant Research. 2019;32(2):31931

Sedighi E, Sirousmehr A, Ramezani M, et al. Investigation the yield and qualitative traits of cotton under different planting dates in barley-cotton double cropping system. Journal of Iranian Plant Echophysiological Research. 2012;6(4):26-36

Shallan MA, Hassan HM, Namich AA, et al. Effect of sodium niroprusside, putrescine and glycine betaine on alleviation of drought stress in cotton plant. American-Eurasian Journal of Agricultural \& Environmental Sciences. 2012;12(9):1252-65

Sharif I, Aleem S, Farooq J, et al. Salinity stress in cotton: effects, mechanism of tolerance and its management strategies. Physiol Mol Biol Pla. 2019:1-14.https://doi.org/10.1007/s12298-019-00676-2

Tan BC, Chin CF, Alderson P. Effects of sodium nitroprusside on shoot multiplication and regeneration of Vanilla planifolia Andrews. In Vitro Cellular \& Developmental Biology-Plant. 2013;49(5):626-30

Wang N, Qi H, Qiao W, et al. Cotton (Gossypium hirsutum L.) genotypes with contrasting K+/Na+ ion homeostasis: implications for salinity tolerance. Acta Physiologiae Plantarum. 2017;39(3):39-77

Wrather J, Phipps B, Stevens W, et al. Cotton planting date and plant population effects on yield and fiber quality in the Mississippi Delta. Journal of cotton science. 2008;12:1-7

Xiao S, Liu L, Wang H, et al. Exogenous melatonin accelerates seed germination in cotton (Gossypium hirsutum L.). PloS one. 2019;14(6):e0216575

Yildirim E, Turan M, Guvenc I. Effect of foliar salicylic acid applications on growth, chlorophyll, and mineral content of cucumber grown under salt stress. Journal of plant nutrition. 2008;31(3):593-612

Zhang K, Guo N, Lian L, et al. Improved salt tolerance and seed cotton yield in cotton (Gossypium hirsutum L.) by transformation with betA gene for glycinebetaine synthesis. Euphytica. 2011;181(1):1-16 
Zheng $C$, Jiang $D$, Liu F, et al. Exogenous nitric oxide improves seed germination in wheat against mitochondrial oxidative damage induced by high salinity. Environ Exp Bot. 2009;67(1):222-

7.https://doi.org/10.1016/j.envexpbot.2009.05.002

\section{Tables}

Table 1: Average temperatures and total rainfalls in the growing seasons during the 2 experimental years

\begin{tabular}{rrrrrr}
\hline Month & \multicolumn{2}{c}{ Average temperature $(\circ \mathrm{C})$} & & \multicolumn{2}{c}{ Total rainfall $(\mathrm{mm})$} \\
\cline { 2 - 3 } \cline { 5 - 6 } & 2017 & 2018 & & 2017 & 2018 \\
\hline January & 5.9 & 5.76 & & 15 & 1.6 \\
February & 6.5 & 9.99 & & 49.9 & 20 \\
March & 12.5 & 17.1 & & 21.4 & 2 \\
April & 18.9 & 17.9 & & 29.4 & 32.2 \\
May & 26.9 & 23.3 & & 14.2 & 17.8 \\
June & 30.86 & 29.52 & & 0 & 0.7 \\
July & 31.02 & 28 & & 2.8 & 0.0 \\
August & 29.86 & 30.4 & & 0.0 & 0.0 \\
September & 25.7 & 26.3 & & 0.0 & 6.5 \\
October & 19.1 & 17.5 & & 0.0 & 35.1 \\
November & 13.7 & 12.5 & & 2.0 & 0.6 \\
December & 7.21 & 6.59 & & 0 & 1.2 \\
\hline
\end{tabular}

Table 2: Physicochemical properties of the soil at the experimental site

\begin{tabular}{|c|c|c|c|c|c|c|c|c|c|c|c|c|}
\hline Manganese & Sodium & Zinc & Copper & Iron & Phosphorus & Potash & \multirow[t]{2}{*}{ (\%) Nitrogen } & Sand & Clay & Silt & \multirow{2}{*}{$\begin{array}{c}\text { EC } \\
\text { (dS } \\
\left.m^{-1}\right)\end{array}$} & \multirow[t]{2}{*}{$\overline{\mathrm{pH}}(1: 5)$} \\
\hline \multicolumn{5}{|c|}{$\left(\mathrm{mg} \mathrm{kg}^{-1}\right)$} & $\mathrm{PPm}$ & & & & $\%$ & & & \\
\hline 7 & 40.5 & 0.55 & 0.46 & 2.42 & 4 & 110 & 0.02 & 63 & 13 & 24 & 10.5 & 7.2 \\
\hline
\end{tabular}

Table 3: The main effects of sowing date, foliage time, and stress modulator type on the yield and yield components 


\begin{tabular}{|c|c|c|c|c|c|c|c|c|c|}
\hline & $\begin{array}{c}\text { Plant } \\
\text { height } \\
(\mathrm{Cm})\end{array}$ & $\begin{array}{l}\text { Branch } \\
\text { number }\end{array}$ & $\begin{array}{c}\text { Boll } \\
\text { number }\end{array}$ & $\begin{array}{c}\text { Boll } \\
\text { weight } \\
(g)\end{array}$ & $\begin{array}{c}\text { Seed } \\
\text { weight } \\
(\mathrm{g})\end{array}$ & $\begin{array}{c}\text { Biological } \\
\text { yield } \\
\left(\mathrm{Kg} \mathrm{ha}^{-1}\right)\end{array}$ & $\begin{array}{c}\text { Seed } \\
\text { cotton } \\
\text { yield } \\
\left(\mathrm{Kg} \mathrm{ha}^{-1}\right)\end{array}$ & $\begin{array}{c}\text { Lint } \\
\text { percent }\end{array}$ & $\begin{array}{r}\text { Lint } \\
\text { yield } \\
(\mathrm{Kg} \\
\left.\mathrm{ha}^{-1}\right)\end{array}$ \\
\hline \multicolumn{10}{|c|}{ Sowing date } \\
\hline Early & $81.8 \mathrm{a}$ & $13.4 \mathrm{a}$ & $14.6 \mathrm{a}$ & $87.0 \mathrm{a}$ & $117 \mathrm{a}$ & 4323 a & 1879 a & $34.8 \mathrm{a}$ & $655 a$ \\
\hline Late & $52.2 \mathrm{~b}$ & $10.5 \mathrm{~b}$ & $7.4 \mathrm{~b}$ & $56.1 \mathrm{~b}$ & $96 \mathrm{~b}$ & $2131 \mathrm{~b}$ & $713 \mathrm{~b}$ & $27.5 b$ & $198 \mathrm{~b}$ \\
\hline \multicolumn{10}{|c|}{ Foliage time } \\
\hline Flowering & $64.2 \mathrm{~b}$ & $11.1 \mathrm{a}$ & $9.5 \mathrm{~b}$ & $69.1 \mathrm{~b}$ & $105 \mathrm{a}$ & 3277 a & $1190 \mathrm{~b}$ & $31.4 \mathrm{a}$ & $395 \mathrm{~b}$ \\
\hline Flowering+bolling & 69.9 a & $12.7 \mathrm{a}$ & $12.4 \mathrm{a}$ & $74.0 \mathrm{a}$ & 108 a & 3177 a & $1402 \mathrm{a}$ & 30.9 a & 458 \\
\hline \multicolumn{10}{|c|}{ Modulator type } \\
\hline Control & $61.3 \mathrm{~b}$ & $9.5 \mathrm{c}$ & $8.0 \mathrm{~b}$ & $55.2 \mathrm{c}$ & $92 \mathrm{c}$ & 2931 c & $1019 \mathrm{c}$ & $28.8 \mathrm{c}$ & $307 c$ \\
\hline GB & $66.4 \mathrm{a}$ & $11.6 \mathrm{~b}$ & $11.6 \mathrm{a}$ & $73.3 \mathrm{~b}$ & $107 \mathrm{~b}$ & $3183 \mathrm{~b}$ & $1225 \mathrm{~b}$ & $32.0 \mathrm{ab}$ & $411 \mathrm{~b}$ \\
\hline SA & $69.5 \mathrm{a}$ & $13.0 \mathrm{a}$ & $11.9 \mathrm{a}$ & $77.1 \mathrm{ab}$ & $120 \mathrm{a}$ & 3487 a & 1467 a & $33.0 \mathrm{a}$ & $504 a$ \\
\hline SNP & $70.9 \mathrm{a}$ & $13.6 \mathrm{a}$ & $12.3 \mathrm{a}$ & $80.6 \mathrm{a}$ & $106 \mathrm{~b}$ & $3308 \mathrm{~b}$ & $1473 \mathrm{a}$ & $30.8 \mathrm{~b}$ & $483 \mathrm{a}$ \\
\hline
\end{tabular}

Similar letters within the same columns denote insignificant differences based on LSD level of 5\%

Table 4: The interaction effects of sowing date and foliage time on plant height, boll number, boll weight, seed cotton yield, and seed weight

\begin{tabular}{ccccccccccc}
\hline & $\begin{array}{c}\text { Plant height } \\
(\mathrm{Cm})\end{array}$ & Boll number & \multicolumn{2}{c}{$\begin{array}{c}\text { Boll weight } \\
(\mathrm{g})\end{array}$} & \multicolumn{2}{c}{$\begin{array}{c}\text { Seed cotton yield } \\
\left(\mathrm{Kg} \mathrm{ha}^{-1}\right)\end{array}$} & \multicolumn{2}{c}{$\begin{array}{c}\text { Seed weight } \\
(\mathrm{g})\end{array}$} \\
\hline & Early & Late & Early & Late & Early & Late & Early & Late & Early & Late \\
Flowering & $75.3 \mathrm{~b}$ & $53.1 \mathrm{c}$ & $12.1 \mathrm{~b}$ & $6.86 \mathrm{c}$ & $82.6 \mathrm{~b}$ & $55.7 \mathrm{c}$ & $1709 \mathrm{~b}$ & $671 \mathrm{~d}$ & $113 \mathrm{~b}$ & $96.3 \mathrm{c}$ \\
Flowering+bolling & $88.3 \mathrm{a}$ & $51.4 \mathrm{c}$ & $16.9 \mathrm{a}$ & $7.85 \mathrm{c}$ & $91.4 \mathrm{a}$ & $56.6 \mathrm{c}$ & $2049 \mathrm{a}$ & $755 \mathrm{c}$ & $121 \mathrm{a}$ & $94.7 \mathrm{c}$ \\
\hline
\end{tabular}

Similar letters within the same columns denote insignificant differences based on LSD level of 5\%

Table 5: The interaction effects of sowing date and stress modulator type on plant height, boll number, biological yield, seed cotton yield, and lint yield

\begin{tabular}{|c|c|c|c|c|c|c|c|c|c|c|}
\hline \multirow[b]{2}{*}{ Modulator type } & \multicolumn{2}{|c|}{$\begin{array}{l}\text { Plant height } \\
\text { (Cm) }\end{array}$} & \multicolumn{2}{|c|}{ Boll number } & \multicolumn{2}{|c|}{$\begin{array}{c}\text { Biological yield } \\
\qquad\left(\mathrm{Kg} \mathrm{ha}^{-1}\right)\end{array}$} & \multicolumn{2}{|c|}{ Seed cotton yield $\left(\mathrm{Kg} \mathrm{ha}^{-1}\right)$} & \multicolumn{2}{|c|}{$\begin{array}{l}\text { Lint yield } \\
\left(\mathrm{Kg} \mathrm{ha}^{-1}\right)\end{array}$} \\
\hline & Early & Late & Early & Late & Early & Late & Early & Late & Early & Late \\
\hline Control & $72.7 \mathrm{~b}$ & $49.9 \mathrm{c}$ & $10.1 \mathrm{c}$ & $5.8 \mathrm{e}$ & 3818 c & 2045 e & $1450 \mathrm{c}$ & 589 e & $469 \mathrm{c}$ & $146 \mathrm{e}$ \\
\hline GB & $77.7 \mathrm{~b}$ & $55.1 \mathrm{c}$ & $15.7 \mathrm{ab}$ & $7.6 \mathrm{~d}$ & $4235 \mathrm{~b}$ & $2130 d$ & $1735 \mathrm{~b}$ & $716 \mathrm{~d}$ & $618 \mathrm{~b}$ & $205 d$ \\
\hline SA & $88.2 \mathrm{a}$ & $50.9 \mathrm{c}$ & $15.3 \mathrm{~b}$ & $8.6 \mathrm{c}$ & $4672 \mathrm{a}$ & $2303 d$ & 2158 a & $776 \mathrm{~d}$ & $775 \mathrm{a}$ & $233 d$ \\
\hline SNP & $88.8 \mathrm{a}$ & $53.1 \mathrm{c}$ & $17.2 \mathrm{a}$ & $7.4 \mathrm{de}$ & 4569 a & 2047 e & $2174 \mathrm{a}$ & $771 \mathrm{~d}$ & $758 \mathrm{a}$ & $207 d$ \\
\hline
\end{tabular}

Similar letters within the same columns denote insignificant differences based on LSD level of 5\% 
Table 6: The main effects of sowing date, foliage time, and stress modulator type on some biochemical properties

\begin{tabular}{|c|c|c|c|c|c|c|c|}
\hline & Chlorophyll & Chlorophyll & & Carotenoid & Proline & $\mathrm{Na}$ & K \\
\hline & \multicolumn{4}{|c|}{$\mathrm{mg} \cdot \mathrm{g}^{-1} \mathrm{FW}$} & $\begin{array}{c}\mathrm{g}^{-} \mu \mathrm{mol} \\
\mathrm{FW}^{1}\end{array}$ & $\mathrm{mg} \cdot \mathrm{g}^{-1}$ & DW \\
\hline \multicolumn{8}{|l|}{ Sowing date } \\
\hline Early & $1.45 \mathrm{a}$ & $1.32 \mathrm{a}$ & $2.78 \mathrm{a}$ & $0.81 \mathrm{a}$ & $10.6 a$ & $61.7 \mathrm{a}$ & $51.3 \mathrm{a}$ \\
\hline \multirow[t]{2}{*}{ Late } & $0.69 \mathrm{~b}$ & $0.87 \mathrm{~b}$ & $1.56 \mathrm{~b}$ & $0.61 \mathrm{~b}$ & $9.8 \mathrm{~b}$ & $52.1 \mathrm{~b}$ & $43.8 \mathrm{~b}$ \\
\hline & Foliage time & & & & & & \\
\hline Flowering & $0.98 \mathrm{~b}$ & $0.98 \mathrm{~b}$ & $1.96 \mathrm{~b}$ & $0.73 \mathrm{a}$ & $9.4 \mathrm{~b}$ & $56.3 \mathrm{a}$ & $45.1 \mathrm{~b}$ \\
\hline \multirow[t]{2}{*}{ Flowering+bolling } & $1.71 \mathrm{a}$ & $1.22 \mathrm{a}$ & $2.39 \mathrm{a}$ & $0.68 \mathrm{~b}$ & $11.05 \mathrm{a}$ & 57.54 & $49.9 \mathrm{a}$ \\
\hline & odulator type & & & & & & \\
\hline Control & $0.58 \mathrm{c}$ & $0.57 \mathrm{c}$ & $1.15 \mathrm{~d}$ & $0.39 \mathrm{~d}$ & $7.45 \mathrm{c}$ & $74.25 \mathrm{a}$ & $\begin{array}{c}42.08 \\
\mathrm{~b}\end{array}$ \\
\hline GB & $1.15 \mathrm{~b}$ & $1.03 \mathrm{~b}$ & $2.18 \mathrm{c}$ & $0.71 \mathrm{c}$ & $10.8 \mathrm{~b}$ & $\begin{array}{c}58.41 \\
\mathrm{~b}\end{array}$ & $48.9 \mathrm{a}$ \\
\hline SA & $1.21 \mathrm{~b}$ & $1.31 \mathrm{ab}$ & $2.48 \mathrm{~b}$ & $0.82 \mathrm{~b}$ & $11.31 \mathrm{a}$ & $41.5 \mathrm{~d}$ & $50.2 \mathrm{a}$ \\
\hline \multirow[t]{2}{*}{ SNP } & $1.38 \mathrm{a}$ & $1.49 \mathrm{a}$ & $2.87 \mathrm{a}$ & $0.91 \mathrm{a}$ & $11.33 \mathrm{a}$ & 53.58 & 48.8 \\
\hline & & & & & & $\mathrm{C}$ & $\mathrm{a}$ \\
\hline
\end{tabular}

Similar letters within the same columns denote insignificant differences based on LSD level of 5\%

Table 7: The interaction effects of sowing date and stress modulator type on chlorophyll a, carotenoids, proline, and $\mathrm{Na}$ and $\mathrm{K}$ contents

\begin{tabular}{|c|c|c|c|c|c|c|c|c|c|c|}
\hline \multirow[b]{2}{*}{ Noudator ly } & \multicolumn{2}{|c|}{$\begin{array}{c}\text { Chlorophyll a } \\
\text { FW.g }{ }^{-1} \mathrm{mg}\end{array}$} & \multicolumn{2}{|c|}{ Cartrenoid } & \multicolumn{2}{|c|}{$\begin{array}{c}\text { Proline } \\
\text { FW. } g^{-1} \mu \mathrm{mol}\end{array}$} & \multicolumn{2}{|c|}{$\begin{array}{c}\mathrm{Na} \\
\mathrm{DW} \cdot \mathrm{g}^{-1} \mathrm{mg}\end{array}$} & \multicolumn{2}{|c|}{$\begin{array}{c}\mathrm{K} \\
\mathrm{DW} \cdot \mathrm{g}^{-1} \mathrm{mg}\end{array}$} \\
\hline & Early & Late & Early & Late & Early & Late & Early & Late & Early & Late \\
\hline Control & $0.73 \mathrm{~d}$ & $0.43 \mathrm{e}$ & $0.53 \mathrm{~d}$ & $0.27 \mathrm{e}$ & $7.6 \mathrm{c}$ & $7.3 \mathrm{c}$ & $65.5 \mathrm{~b}$ & $83.0 \mathrm{a}$ & $40.6 \mathrm{e}$ & $43.5 \mathrm{~d}$ \\
\hline GB & $1.59 \mathrm{~b}$ & $0.71 \mathrm{~d}$ & $0.71 \mathrm{bc}$ & $0.69 \mathrm{c}$ & $10.9 \mathrm{ab}$ & $10.7 \mathrm{ab}$ & $49.0 \mathrm{c}$ & $67.8 \mathrm{~b}$ & $57.6 \mathrm{a}$ & $40.1 \mathrm{e}$ \\
\hline SA & $1.71 \mathrm{a}$ & $0.70 \mathrm{~d}$ & $0.87 \mathrm{~b}$ & $0.78 \mathrm{~b}$ & $11.7 \mathrm{ab}$ & $11.0 \mathrm{a}$ & $45.83 \mathrm{c}$ & $37.1 \mathrm{~d}$ & $47.3 \mathrm{c}$ & $53.1 \mathrm{~b}$ \\
\hline SNP & $1.81 \mathrm{a}$ & $0.95 \mathrm{c}$ & $1.10 \mathrm{a}$ & $0.72 \mathrm{~b}$ & $12.4 \mathrm{a}$ & $10.3 \mathrm{~b}$ & $48.1 \mathrm{C}$ & $59.0 \mathrm{c}$ & $59.1 \mathrm{a}$ & $38.4 \mathrm{f}$ \\
\hline
\end{tabular}

Similar letters within the same columns denote insignificant differences based on LSD level of 5\%

\section{Figures}




\section{$\square$ Flowering aflowerin+Bolling}

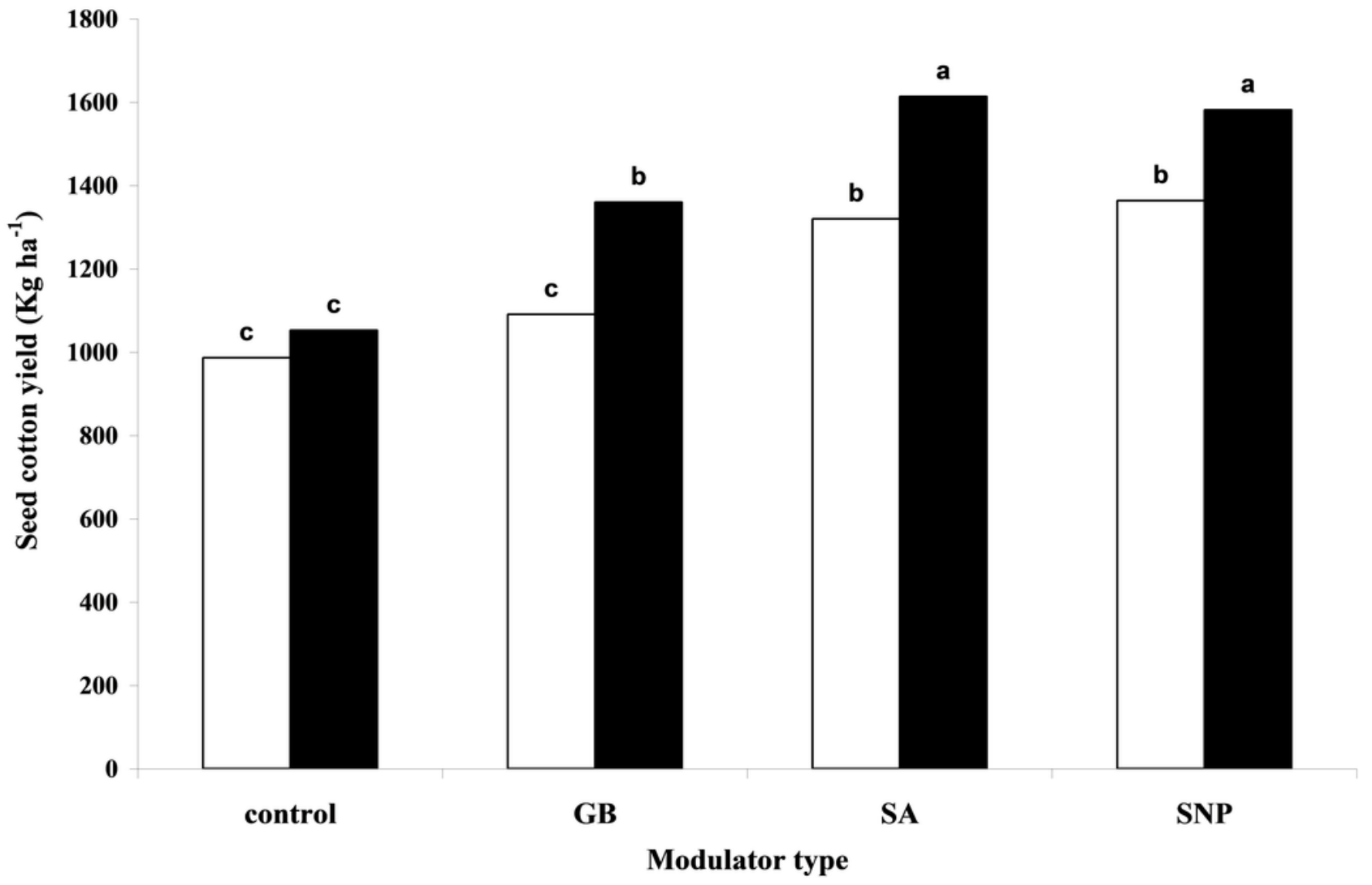

Figure 1

The interaction effects of modulator type and foliage time on seed cotton yield 


\section{$\square$ Flowering $\square$ Flowerin+Bolling}

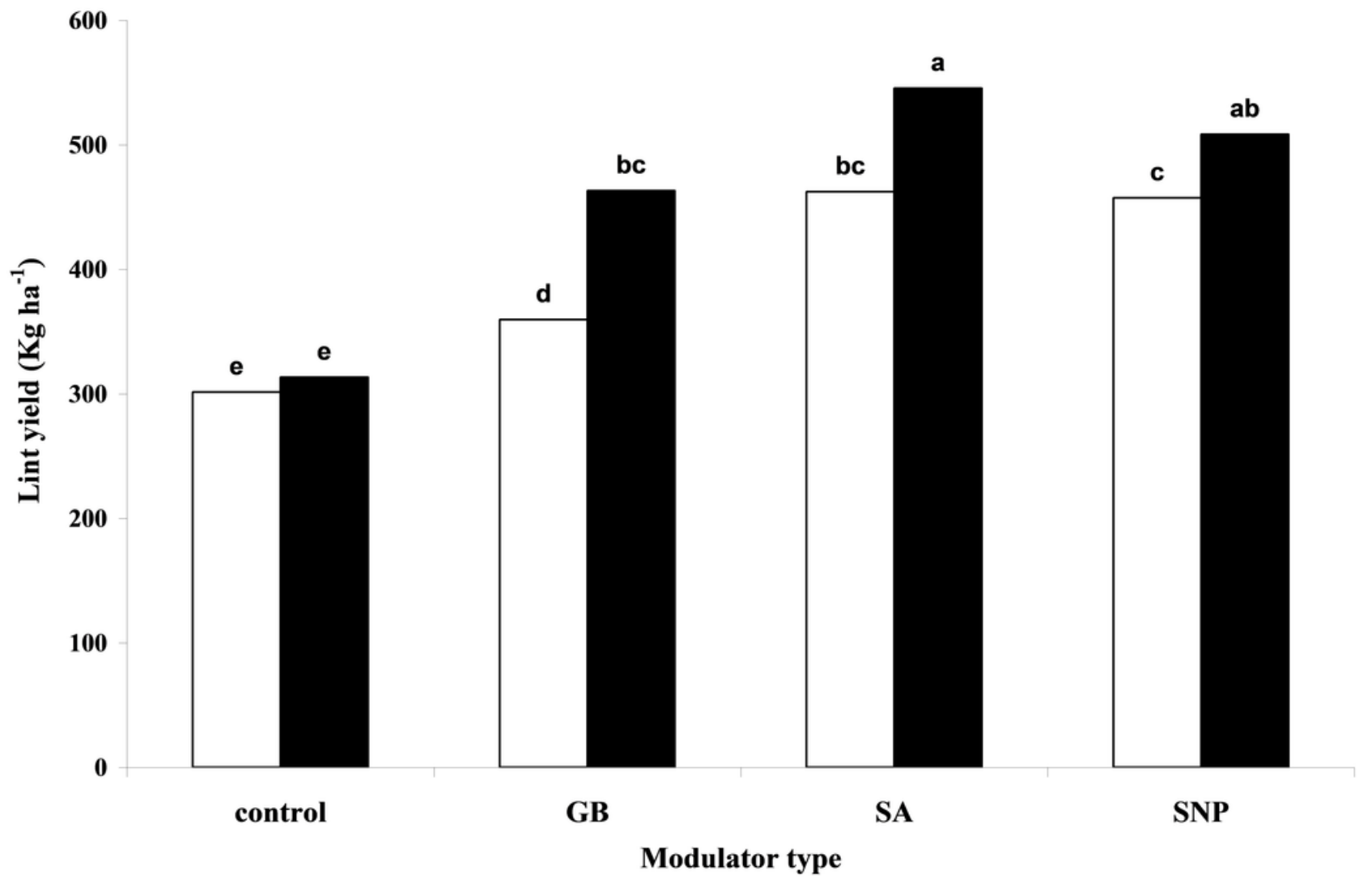

Figure 2

The interaction effects of modulator type and foliage time on lint yield 